\title{
SPATIO-TEMPORAL ANALYSIS OF LAND USE/LAND COVER CHANGE THROUGH OVERLAY TECHNIQUE IN KINNAUR DISTRICT OF WESTERN HIMALAYA
}

\section{ANÁLISIS ESPACIO-TEMPORAL DEL USO DE LA TIERRA / CAMBIO DE LA CUBIERTA DE LA TIERRA A TRAVÉS DE LA TÉCNICA DE REVESTIMIENTO EN EL DISTRITO DE KINNAUR DE HIMALAYA OCCIDENTAL}

\author{
Rajan Maurya ${ }^{1 *}$, V.S. Negi ${ }^{2}$ and B.W. Pandey ${ }^{1}$ \\ ${ }^{1}$ Department of Geography, Delhi School of Economics, University of Delhi, Delhi- \\ 110007 \\ ${ }^{2}$ Department of Geography, Shaheed Bhagat Singh College (Ev.), Sheikh Sarai, \\ University of Delhi, Delhi-110067 \\ *Corresponding Author: Email: rajanmaurya.73@gmail.com
}

\begin{abstract}
Globalisation is irrevocable as well as its dependency on natural resources which is increasing at an unprecedented pace and this growing demand indirectly contributes to the depletion of natural resources. Major drivers of globalisations can be directly linked to the changes in Land use/Land cover (LULC). It is within the mandate of LULC to facilitate in sustainable planning and management of natural resources and in addition to management, it also mandatory to monitor and evaluate the changes in environment. In order to identify the land use pattern, many researchers from all over the world use many remote sensing and Geographical Information System (GIS)-based model in their research. However, this study investigates the changes in land use pattern by adopting digital change detection model with geo-referenced multi-temporal remote sensing data. It then further analyses the spatial-temporal variation, based on the secondary data, of LULC in the Kinnaur district of Himachal Pradesh. Accordingly, Landsat imageries are gathered from the United States Geological Survey (USGS) for a different period like Landsat TM, Landsat ETM +, and Landsat OLI. In the past few decades, developments in Kinnaur in terms of hydro projects; construction of dams, tunnels and roads, show a trend of conversion in the pattern of land use. This study develops a result which shows an increase in the built-up area, land under agricultural and Horticultural activities and even increase in precipitation level (in the form of snow) in the district and gradual decrease in the area covered by wasteland over a period of 1990 to 2018.
\end{abstract}

Keywords: Natural Resources, Land Use/ Land Cover, Kinnaur, Hydroelectric Projects. 


\section{RESUMEN}

La globalización es irrevocable, así como su dependencia de los recursos naturales, que está aumentando a un ritmo sin precedentes y esta demanda creciente contribuye indirectamente al agotamiento de los recursos naturales. Los principales impulsores de las globalizaciones pueden vincularse directamente a los cambios en el uso del suelo / cobertura del suelo (LULC). Está dentro del mandato de LULC facilitar la planificación y gestión sostenible de los recursos naturales y, además de la gestión, también es obligatorio monitorear y evaluar los cambios en el medio ambiente. Para identificar el patrón de uso de la tierra, muchos investigadores de todo el mundo utilizan muchos modelos basados en el Sistema de Información Geográfica (SIG) y teledetección en sus investigaciones. Sin embargo, este estudio investiga los cambios en el patrón de uso de la tierra mediante la adopción de un modelo de detección de cambio digital con datos de detección remota multitemporales geo-referenciados. Luego analiza más la variación espacio-temporal, basada en los datos secundarios, de LULC en el distrito de Kinnaur de Himachal Pradesh. En consecuencia, las imágenes de Landsat se recopilan del Servicio Geológico de los Estados Unidos (USGS) para un período diferente, como Landsat TM, Landsat ETM + y Landsat OLI. En las últimas décadas, desarrollos en Kinnaur en términos de proyectos hidroeléctricos; La construcción de presas, túneles y carreteras, muestra una tendencia de conversión en el patrón de uso del suelo. Este estudio desarrolla un resultado que muestra un aumento en el área urbanizada, tierra bajo actividades agrícolas y hortícolas e incluso un aumento en el nivel de precipitación (en forma de nieve) en el distrito y una disminución gradual en el área cubierta por tierras baldías durante un período de 1990 a 2018.

Palabras clave: Recursos naturales, Uso del suelo / Cubierta del suelo, Kinnaur, Proyectos hidroeléctricos.

\section{INTRODUCTION}

Activities, especially in the anthropogenic activities such as deforestation, constructions, deconstruction, and reconstruction of built-up areas such as infrastructure, development, urbanization, tourist inflow and related development all have led to alterations in the dynamics of land use and land cover (LULC). What matters about land use dynamics is directly proportional to the quantum of anthropogenic interventions, and the intent that drives development (Negi 2009). The drivers may have short term as well as long term impacts which over time may turn into blessings for generations to come or it can be vice-versa as well (Chawla et al. 2012). To understand the changing dynamics, multiple techniques are applied by academicians to understand the depth of an ongoing study. Geospatial and satellite data strengthens research understanding of a changing landscape over a period that meets parameters of a research inquiry to fulfil the gaps (Singh 1996).

Infrastructure development has been recognised as one of the primary factors which have led to large scale LULC change. And the responsible agent for such changes is anthropogenic and development activities (Reid et al. 2000). However, socio-economic goals, luxurious desires and technological advancements have been on an accelerating trajectory with each passing day. Most of these developments have cost dear to balance nature, which has subsequently declined the integrity of the ecosystem (Gupta 2007). At the same time, land use transformation has become a compelling choice and adaptive mechanism to cater to the needs of people (Pandey 2002). Development activities have been increasing at an extreme rate to accommodate people to meet their economic needs 
and basic requirements (Mahmood et al. 2010). Rapid growth in anthropogenic activities in the Himalayan states of India has created an imbalance between upland -lowland interaction. This causes degradation of the natural ecosystem of Himalaya and supporting services of it which leads to rapid change in land use pattern (Pandey and Jha 2012). Destruction of upland areas has impacted on lowland system, which resulted in extreme weather conditions like floods and drought at the same place, which also indicated the imbalance between natural and anthropogenic activities (Pandey et al. 2017).

Currently, demand for $24 X 7$ power supply put load on every drainage system which drastically changes the land uses by the establishment of hydroelectric projects (HEP) on major streams and nallas of the Kinnaur district, which makes it one of the highest power generation district of Himachal Pradesh. This district experienced a revolution in apple orchard farming during the decades of $90 \mathrm{~s}$, just because of the demand of 'Kinnauri apple' in the local and national market. Apple orchard farming has changed the economy of the district and lifestyle of tribal communities which has led to rapid change in land-use patterns of district along the valley of the Sutlej river (Maurya and Mishra 2017). The improved economic condition of the tribal community has also led to an increase in a builtup area and decrease in the wasteland, open forest or outer forest land is now converted into orchards of apple and other fruits (Singh et al. 1992). In the present day, research related to spatial-temporal analysis is widespread to find the intent of dynamics of it; and to understand the level of change on the surface to perform any development activities in the interested area. The changing pattern of development and uneven extent of growth at an alarming rate in the mountainous region give this study more critical. Due to variation in temperature and extreme weather condition, it becomes essential to have a sustainable model of development and growth (Prasad et al. 2016). For this purpose, the study of LULC is to gain more attention in research fraternity. By dint of its importance, an attempt is carried out to analyse the LULC pattern and level of development activities in Kinnaur district.

The objectives of the study are investigating the land use/land cover pattern of Kinnaur district and examine the impact of development works in Kinnaur district on LULC pattern.

\section{MATERIAL AND METHODS}

Study Area: Kinnaur is situated in the western part of the Himalaya (figure 1). It is one of the scheduled tribe districts of the Himachal Pradesh which is located in the eastern part bordered with Tibet (China). It adjoins with other districts of Himachal Pradesh like in the west part Kullu, Lahul and Spiti in North, and Garhwal Himalaya in the south. Its latitudinal extent is $31^{\circ} 35^{\prime} 40^{\prime \prime}$ to $31^{\circ} 34^{\prime} 42^{\prime \prime}$ north, and the longitudinal length is $77^{\circ} 52^{\prime} 38^{\prime \prime}$ to $78^{\circ} 51^{\prime} 28^{\prime \prime}$ East and found in the Toposheet of Survey of India, Toposheet No. 53E/14/3, $53 \mathrm{E} / 14 / 6$.

It has three development blocks, i.e., Nichar, Kalpa and Poo. Nichar region has dense forest, and the density of forest gradually decreases from lower to the upper area of Kinnaur. The Hindu population dominates the lower region of the district, the middle part shows the mixed culture of Hinduism and Buddhism, and the Buddhist people dominate the upper part (Lata R. et al. 2015). Sutlej river enters through Shipki La Pass and passes throughout the district in a south-west direction, and enter into Shimla district. Kinnauri and Hindi are the prominent languages spoken in the district. 


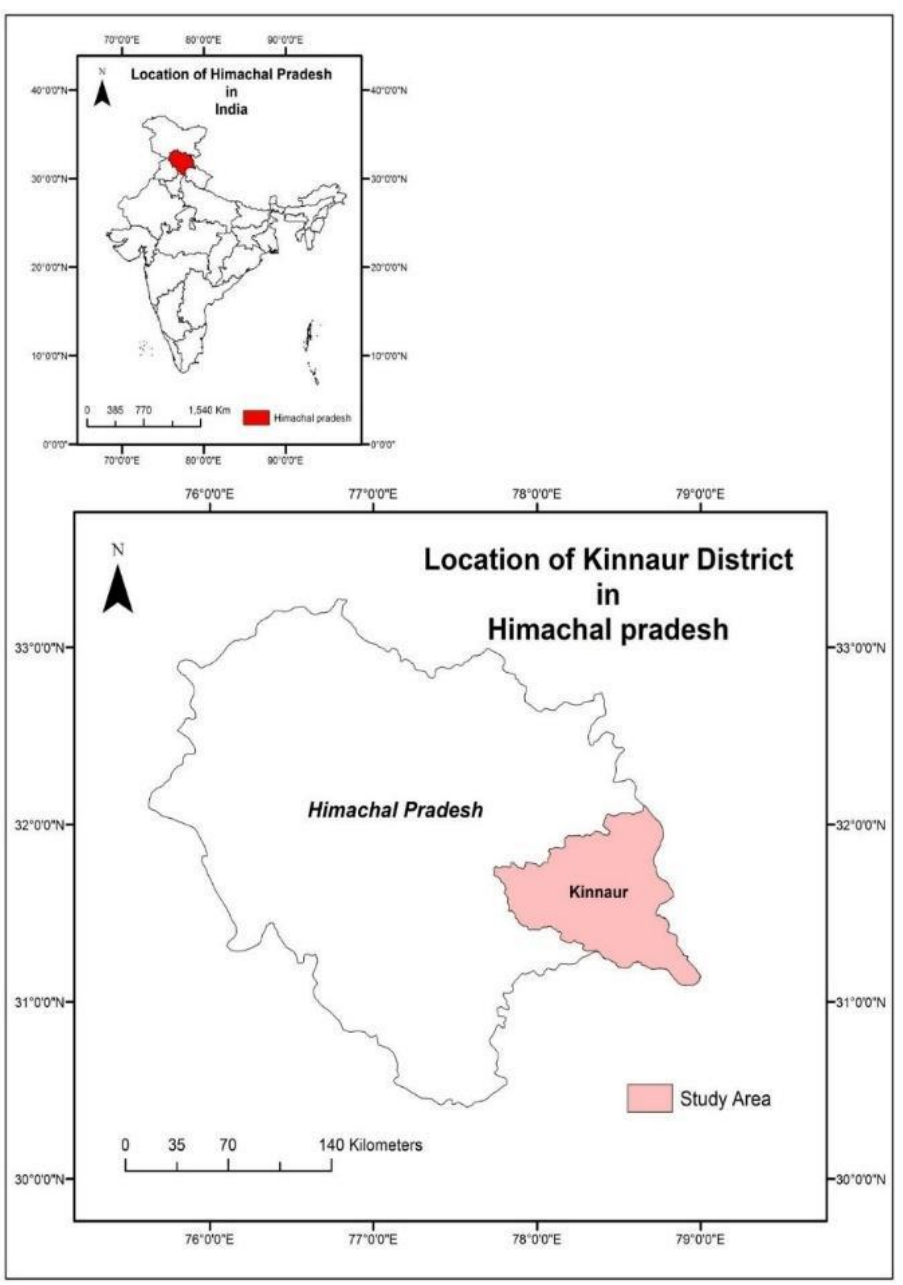

Figure 1. Location of Study Area. Source: Prepared by the author with the help of map of Census of India, 2011

Images obtention and processing: The Landsat images of 1990 (TM), 2005 (ETM + ) and 2018 (OLI) are collected from the United States Geological Survey (USGS). Further, in the study we have used eight spectral bands (1-8) for all the images to perform the layer stacking. In order to neglect the scan line corrector (SLC) error of the Landsat $(E T M+)$ images, we have performed the focal analysis function from the spatial enhancement option in Erdas Imagine 9.2. However, this function is especially used to eradicate the SLC error. It actually fills the gaps of the satellite images based on its neighbouring pixels. Similarly, we have also used the Landsat images of the same period to authenticate the consistency of the images. For the preparation of the map ArcGIS 10 software has been used. This application also used to delineate the shapefile of Kinnaur district based on the revenue map, which is converted into WGS-1984 projection system. After that, Erdas Imagine 9.2 is used to make a vector layer of shapefile as AOI to extract boundaries from the satellite images for both time frames. Supervised classification technique has been performed after selecting six land use classes, i.e. build-up, snow, vegetation, waterbody, wasteland, and agriculture. After classifying all the three images, change detection technique has been applied to identify the changes in attributes of a particular region over the period. 
Two continuous raster images are allowed as input in the change detection matrix technique. There is a threshold value defined by the user for the change of a single pixel, and it should be marked as the change from one year to the next year. After this process, a highlighted file is created; and in this file, we can identify the increase or decrease in the particular threshold value by marking the pixel. We have to classify the demarcated/highlighted changes in per cent as increased or decreased more than 10 per cent respectively. Those highlighted pixels in the map could represent the area where construction of new roads, dams, horticulture products, and settlement area has been constructed on wasteland or forest area. This map gives us a quick overview of changes in a particular area over two time periods. It is like spatial and temporal analysis of that area with the changes in land use.

The Matrix analysis, which is a tool of GIS analysis, is used to compare two thematic images of different years. In this, we have given two supervised classification images as input and compared two classified sets of data. Then the elimination of false positives due to difference in radiometry. For example, three detailed images were layered into the remote sensing process and had near about three classes in each file of snow or any other LULC pattern. After the matrix operation resulting data shows a thematic range of particular classes such as 'was snow is now snow' or 'was wasteland is now wasteland'. If it shows no change from the previous year, then it means there is no change in snow area or wasteland (for each land use classes, the same process is done) in the present year. It gives an idea about the changes in land use pattern from last year.

Land Use/Land Cover Change (1990-2018): In the present study, to identify the change in land use, and land cover in Kinnaur district, we have used satellite images of the Landsat (TM) image of January 13, 1990, Landsat (ETM+) image of December 16, 2005, and Landsat (OLI) image of December 28, 2018 in this research paper and by using maximum likelihood classifier algorithm, supervised classification has been performed.

\section{RESULTS AND DISCUSSION.}

Land Use pattern shows changes in physical factors of any area within a period. It also shows a link between the historical and socio-economic differences in a particular area (Kumar et al. 2013). Due to the growth of population in Kinnaur district and limited natural resources leads to pressure on the environment and ecology of this region (table 1). It can be seen that the decadal growth rate of population is increasing day by day because of the modern health system (figure 2). Enormous pressure is on natural resources, and it becomes imperative to know the pattern of LULC for the sustainability of Kinnaur district. During 1990, in Kinnaur district area under snow and wasteland is larger than the area under built-up, vegetation, water body and agriculture (figure 3). Due to globalisation, increased demand of Kashmiri apple in the international market, and to fulfil the national requirement, the apple of Himachal and Uttarakhand are rapidly increased. In Kinnaur district, horticulture land under the vegetation is increased along both sides of the river Sutlej, and settlement area near Nichar, Sangla, and Kalpa valley. There is no forest cover in the upper part of Kinnaur; upper part of vegetation cover is dominated with apple orchards, apricot, wall nut orchards and many other dry fruits, shrubs and alpine pasture (figure 4). 


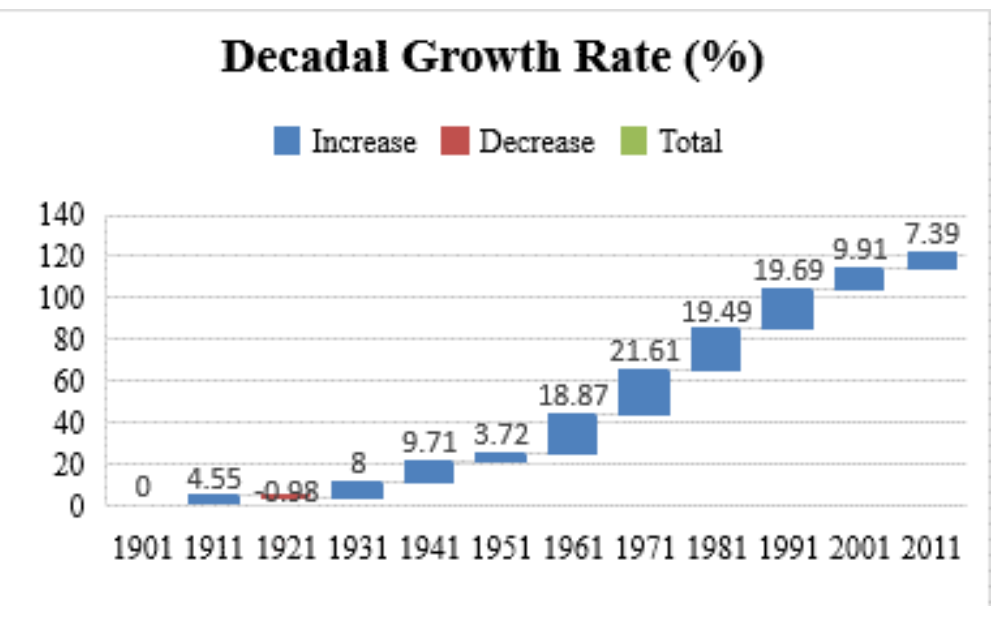

Figure 2. Decadal Growth Rate of Population of Kinnaur District. Source: Census of India, 2011

Table 1. Population, Decadal Growth Rate, and Population Density of Kinnaur District.

\begin{tabular}{ccccc}
\hline $\begin{array}{c}\text { Sl. } \\
\text { No. }\end{array}$ & Year & Population & $\begin{array}{c}\text { Decadal Growth Rate } \\
(\%)\end{array}$ & $\begin{array}{c}\text { Population Density } \\
\text { (person per sq. km) }\end{array}$ \\
1 & 1901 & 27,232 & NA & NA \\
2 & 1911 & 28,470 & $(+) 4.55$ & NA \\
3 & 1921 & 28,191 & $(-) 0.98$ & NA \\
4 & 1931 & 30,445 & $(+) 8.00$ & NA \\
5 & 1941 & 33,238 & $(+) 9.71$ & NA \\
6 & 1951 & 34,475 & $(+) 3.72$ & NA \\
7 & 1961 & 40,980 & $(+) 18.87$ & NA \\
8 & 1971 & 49,835 & $(+) 21.61$ & NA \\
9 & 1981 & 59,547 & $(+) 19.49$ & 11 \\
10 & 1991 & 71,270 & $(+) 19.69$ & 12 \\
11 & 2001 & 78,334 & $(+) 9.91$ & 13 \\
12 & 2011 & 84,121 & $(+) 7.39$ & \\
\hline
\end{tabular}

Source: Census of India, 2011 


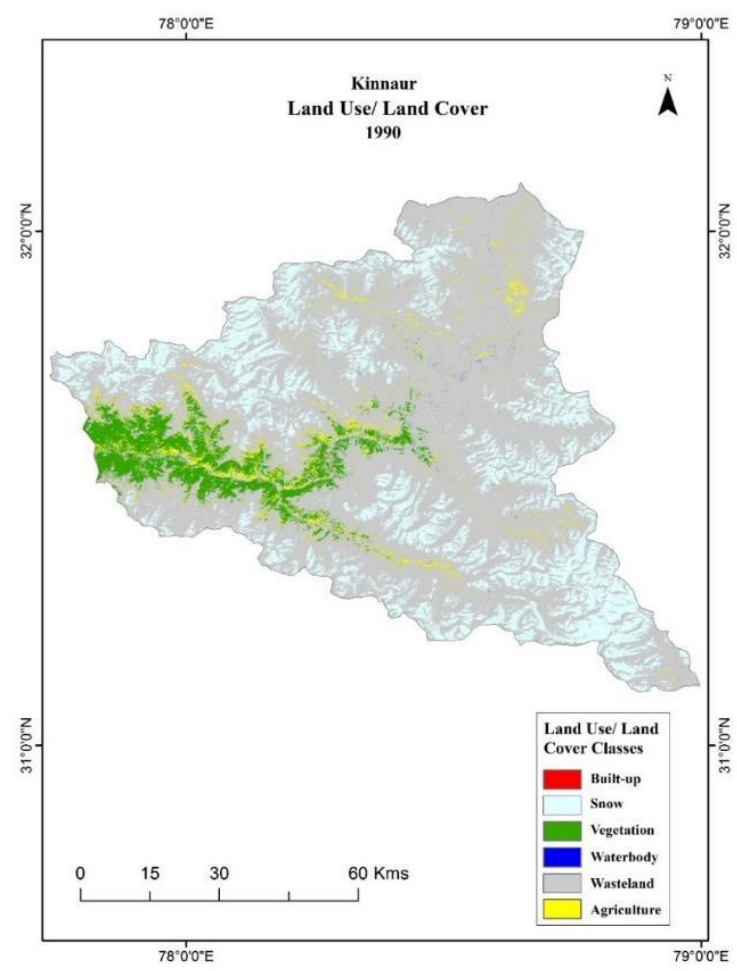

Figure 3. Land Use of Kinnaur District by Supervised Classification, 1990. Source: Prepared by author with the help of LANDSAT TM imagery.

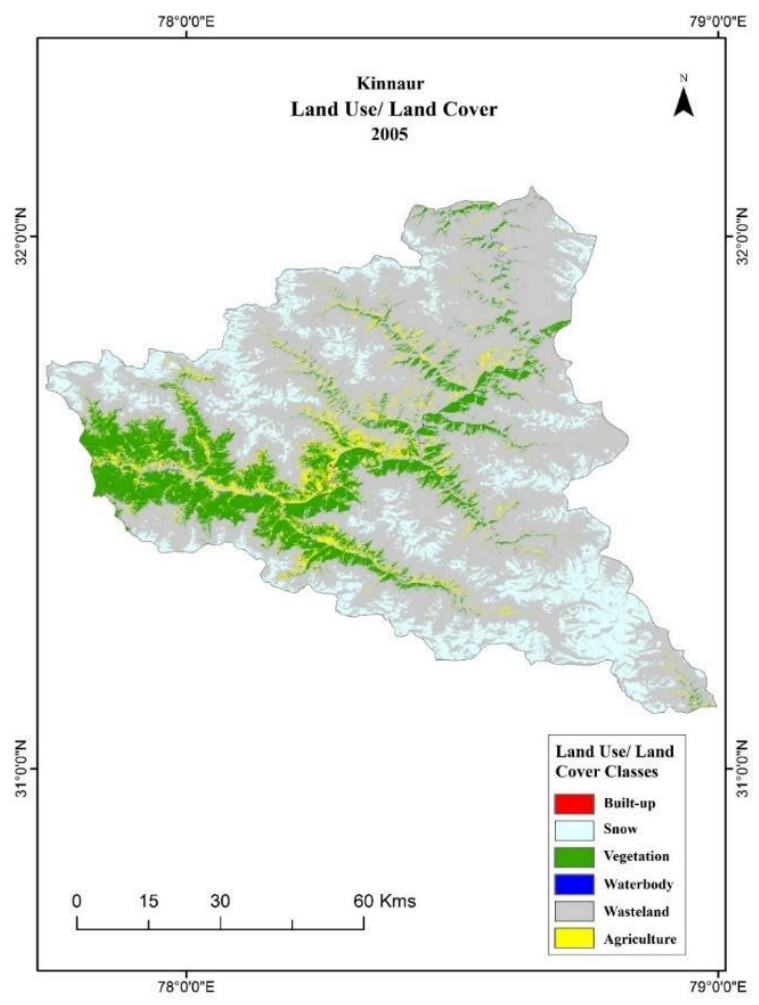

Figure 4. Land Use of Kinnaur District by Supervised Classification, 2005. Source: Prepared by author with the help of LANDSAT ETM+ imagery. 
The most built area is increased in Kalpa (Rekong peo), Nichar (near Bhaba Nagar), and Sangla in Baspa Valley. Climatic variation of grains changed the pattern of demand in the lower part of the valley or the plains region. Agricultural land is rapidly increased in the last few decades because of the increasing demand of the cereals, potatoes, peas and local grains in the lower area (figure 5). The land use/land cover pattern shows an increasing trend in agriculture land, built-up area, and vegetation area. It is observed that in the year 1990, 2.7 per cent, 0.1 per cent and 6.5 per cent of the overall geographical area was covered by agriculture, built-up and vegetation cover respectively. It shows the decreasing amount to 15.6 per cent in agriculture, 0.6 per cent in built-up, and 14.7 per cent in vegetation covered in 2018 (figure 6). The reason behind increased per cent in vegetation is the encroachment of open forest land under the plantation of horticulture products like apple, cherry, and dry fruits.

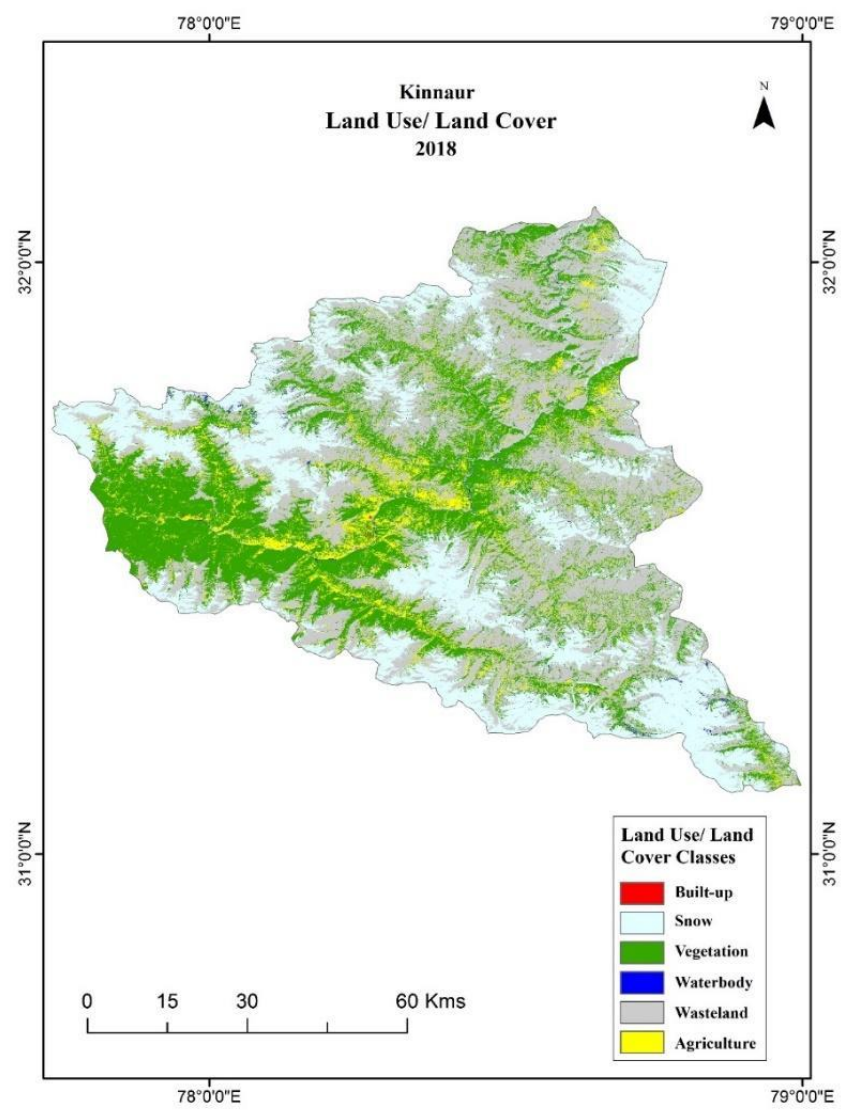

Figure 5. Land Use of Kinnaur District by Supervised Classification, 2018. Source: Prepared by author with the help of LANDSAT OLI imagery.

Wasteland area is reduced rapidly from 1990 to 2018. It is observed that 70.1 per cent to 65.0 per cent from 1990 to 2005 and 43.8 per cent in 2018 . Snow cover data shows that there is an uneven pattern of increase and decrease of snowfall over the few decades. As it is evident from that in 1990, snow cover was 20.6 per cent of the total geographical area and then 17.5 per cent, 25.0 per cent in 2005 and 2018 respectively (table 2). This increasing and decreasing amount of snow is related to local phenomenon and the rising temperature of this area. Every alternate year rate of snowfall is high. Due to many development activities, increased dust particle, which resulted in temperature 
increase. It is the reason behind the uneven pattern of snow in this region. Although water body is increased only in the rainy season otherwise in average weather conditions, it shows a lower amount of water in the river beds and its tributaries. By the change detection matrix technique, a matrix table has been made to identify the changes in land use pattern between 1990 to 2005, and 2005 to 2018. It is evident from the matrix table that maximum change is notified in the wasteland from vegetation area is $152 \mathrm{sq} . \mathrm{Km}, 24$ sq. $\mathrm{Km}$ of snow area is converted into vegetation cover, and $4 \mathrm{sq} . \mathrm{Km}$ area is from vegetation to agriculture land (table 3 ). This transformation is due to policy implication and support in horticulture, especially in apple orchards, hybrid seed nursery, and free plant distribution from the state government of Himachal Pradesh. Vegetation cover is high due to apple and other dry fruits orchards in the upper part of the district. The economy of the Kinnaur is based on apple production, and changes in lifestyle are also significant changes due to profit in it. People of Kinnaur are focusing on the production of apple because of the high demand for 'Kinnauri apple' in the market; this economy is changed from rural economy to a market-based economy and more profit gain.

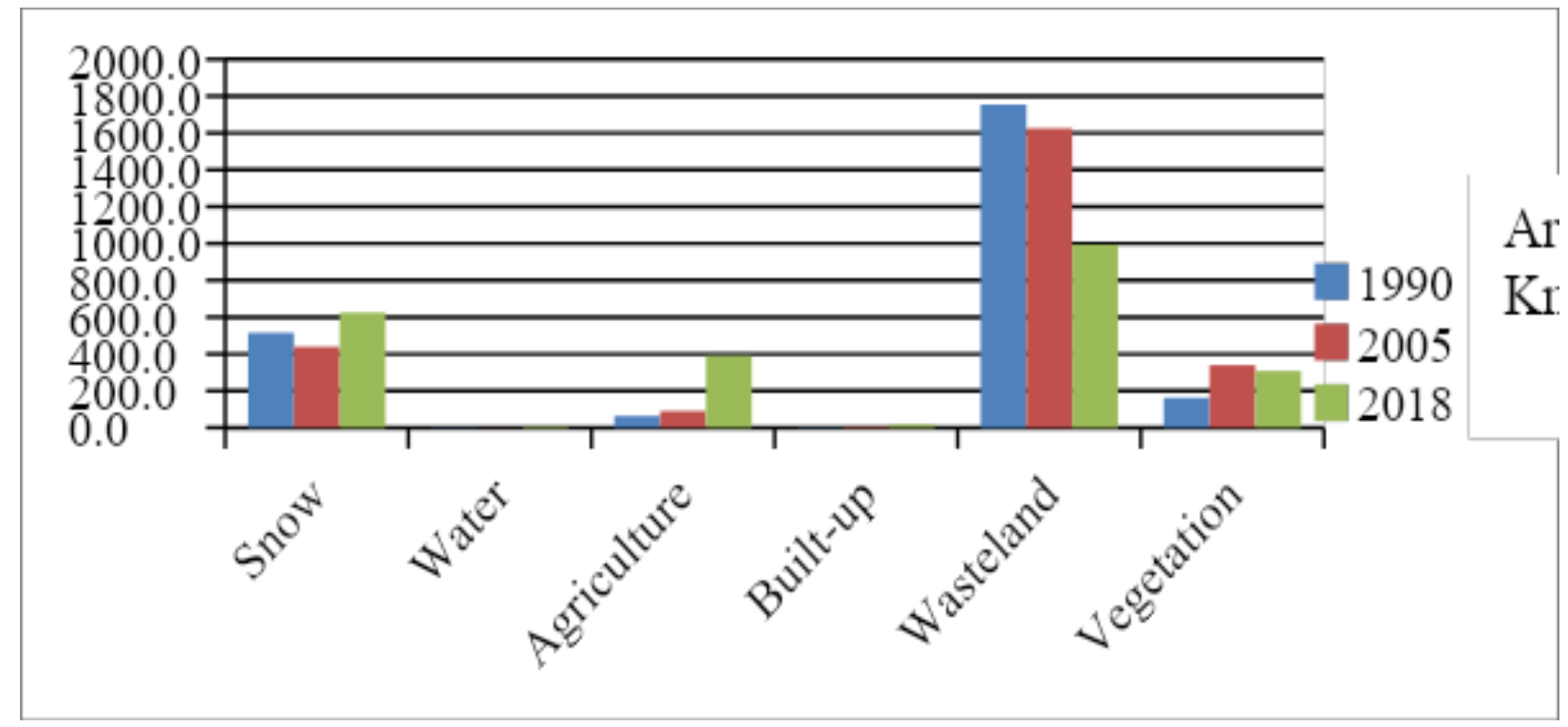

Figure 6. Land Use/Land Cover change between 1990 to 2018. Source: Calculated by author from LANDSAT imageries. 
Table 2. Land Use/Land Cover Change 1990-2018

\begin{tabular}{|c|c|c|c|c|c|c|c|c|c|}
\hline \multirow{2}{*}{$\begin{array}{c}\text { Year } \\
\text { Land use } \\
\text { Class }\end{array}$} & \multicolumn{2}{|c|}{1990} & \multicolumn{2}{|c|}{2005} & \multicolumn{2}{|c|}{2018} & \multirow{2}{*}{$\begin{array}{c}\text { Change } \\
\text { between } \\
\text { 1990-2005 } \\
(\%)\end{array}$} & \multirow{2}{*}{$\begin{array}{c}\text { Change } \\
\text { between } \\
\text { 2005-2018 } \\
(\%)\end{array}$} & \multirow{2}{*}{$\begin{array}{c}\text { Change } \\
\text { between } \\
1990-2018 \\
(\%)\end{array}$} \\
\hline & $\begin{array}{l}\text { Area } \\
(\mathrm{km})\end{array}$ & $\%$ & $\begin{array}{l}\text { Area } \\
\left(\mathrm{km}^{2}\right)\end{array}$ & $\%$ & $\begin{array}{l}\text { Area } \\
\left(\mathrm{km}^{2}\right)\end{array}$ & $\%$ & & & \\
\hline Snow & 515.2 & 20.6 & 439.0 & 17.5 & 624.9 & 25.0 & -15 & 42.85 & 21 \\
\hline Water & 2.3 & 0.2 & 1.0 & 0.1 & 9.2 & 0.4 & -50 & 300 & 100 \\
\hline Agriculture & 66.5 & 2.7 & 90.0 & 3.6 & 389.7 & 15.6 & 33.33 & 333 & 477 \\
\hline Built-up & 3.4 & 0.1 & 7.6 & 0.3 & 16.2 & 0.6 & 200 & 100 & 500 \\
\hline Wasteland & 1754.1 & 70.1 & 1626.3 & 65.0 & 1095.4 & 43.8 & -7.27 & -32.61 & -37.51 \\
\hline Vegetation & 161.8 & 6.4 & 339.4 & 13.5 & 367.9 & 14.7 & 110 & 8.88 & 129.68 \\
\hline Total & 2503.3 & 100 & 2503.3 & 100 & 2503.3 & 100 & 00 & 00 & 00 \\
\hline
\end{tabular}

Source: Calculated by Author from LANDSAT Imageries

Table 3. Land Use/ Land Cover Change Detection Matrix, 1990-2005

\begin{tabular}{|c|c|c|c|c|c|c|c|c|}
\hline \multicolumn{9}{|c|}{2005} \\
\hline & LULC & Built-up & Snow & Vegetation & Water & Wasteland & Agriculture & Total \\
\hline & CLASS & & & & & & & \\
\hline 1 & Built-up & 3 & 0 & 0 & 0 & 0 & 0 & 3 \\
\hline 9 & Snow & 0 & 432 & 24 & 0 & 58 & 0 & 515 \\
\hline 9 & Vegetation & 3 & 1 & 154 & 0 & 0 & 4 & 162 \\
\hline \multirow[t]{4}{*}{0} & Water & 0 & 0 & 0 & 1 & 0 & 1 & 2 \\
\hline & Wasteland & 0 & 6 & 152 & 0 & 1568 & 28 & 1754 \\
\hline & Agriculture & 1 & 0 & 9 & 0 & 0 & 56 & 67 \\
\hline & Total & 8 & 439 & 339 & 1 & 1626 & 90 & \\
\hline
\end{tabular}

Source: Calculated by the author with the help of LANDSAT imageries.

It is evident from the LULC change detection that from 1990 to 2005 decreased amount of snow, water and wasteland, in the middle and southern-east part of Kinnaur district; it is also observed that unchanged area is scattered every part of the district which shows the permanent vegetation in the form of dense forest, wasteland and snow on the peak of mountain (figure 7). If we compare it with the change detection map of 2005 to 
2018, it is easily identified that unchanged area in the form of some snow, wasteland, vegetation area and some settlement part in the river valley are maximum than the other parts due to local phenomenon. Some increase area shows the horticulture and grasses medicinal plants on alpine pasture on the upper part of the mountain. Increased area is shows the agriculture land, and increase in the density of vegetation. Some decrease part is the shows in the valley region which might be the result of reduce in vegetation due to landslides, mass wasting in the result of tunnelling and road construction (figure 8).

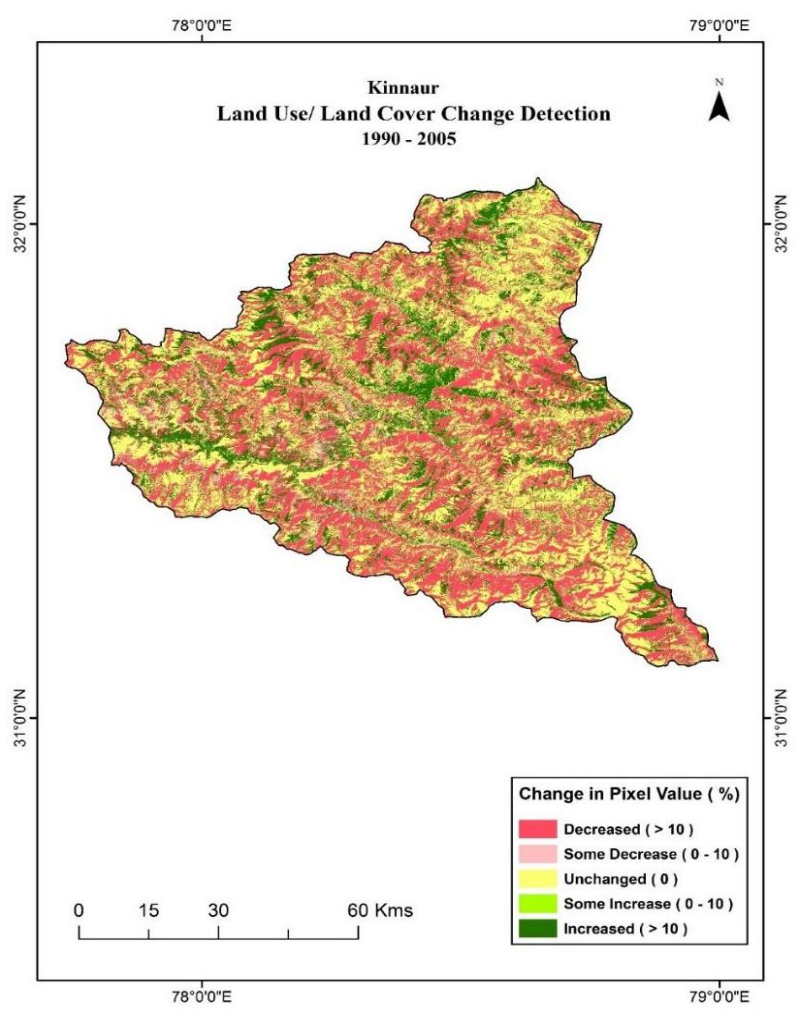

Figure 7. Land Use/ Land Cover Change Detection of Kinnaur, 1990-2005. Source: Prepared by the author with the help of LANDSAT imageries. 


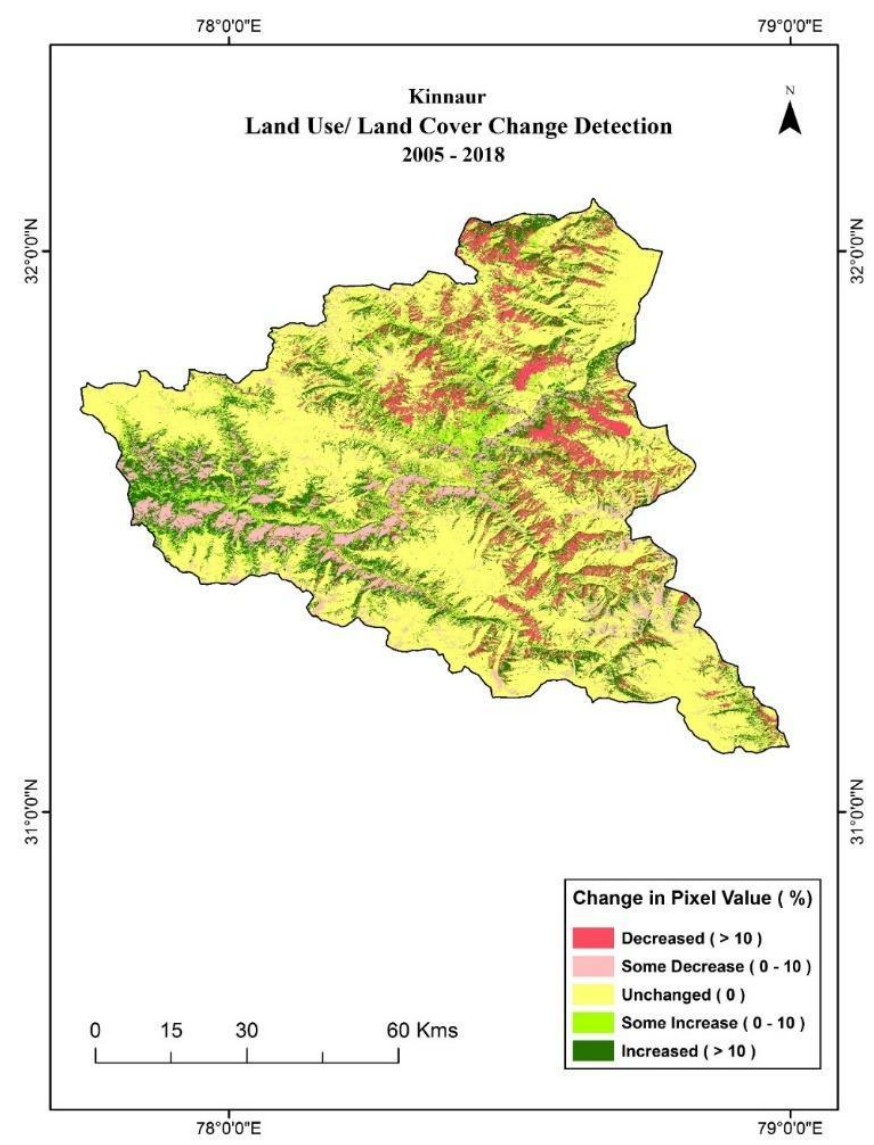

Figure 8. Land Use/ Land Cover Change Detection of Kinnaur, 2005-2018. Source: Prepared by the author with the help of LANDSAT imageries.

It has also been evident from the matrix table that during 2005 to 2018 about 36 sq. $\mathrm{Km}$ area changed into vegetation from wasteland, and $296 \mathrm{sq} . \mathrm{Km}$ from wasteland to agriculture land (table 4). Reason behind the changes in snow cover is changes in temperature and rainfall amount. This temperature changes resulted in increasing amount of species of the medicinal and aromatic plants in this area. The monoculture of chir/chil and chilgoza pine is also affected by the increasing horticulture land (Singh and Pandey 1995). In Sangla valley (Baspa Valley) high altitude villages like Batseri, Rakchham have found apple orchards for the fulfilment of economically needs. Changes in land use pattern are clearly evident in these areas. Kinnaur district has the highest electric production among the other region of Himachal Pradesh; because it has many big and small HEP. The natural ecosystem is degrading due to construction of the HEP in the district. Extreme weather condition due to rise in temperature also harms the ecosystem. Activities like the construction of the road in remote villages, towers for power supply, changes in lifestyle, the encroachment of forest land for horticulture activities, and changing patterns of agriculture in high altitude area have altered the trend in land use/land cover (Lambin et al. 2001).

Status of changes in LULC pattern in Kinnaur: LULC change is a human-induced activity by which land pattern is changed over a while. These dynamic changes have a significant impact on the type of land use pattern associated with an ecological perspective (Negi 2009). Increasing trend in population of this region show the pressure on the natural resources which is increased in every census year (figure 9). From the formation of the 
district and till now, the area of land is limited but the population is significantly increased. Kinnaur district scenic natural beauty attracts the foreign as well as a national tourist; it is also situated on the way of Kaza (in Lahul-Spiti) which is renowned for its great adventure in Zanskar range, and the isolation and bound with the natural beauty. In ancient time it is a famous market for the travellers of Tibet. It also bordered with China which is very important for the geostrategic point of view. Highway of this region is strategically significant for the national security, and it leads to construction and widening of roads. From Kinnaur, you traverse the route along Hindustan - Tibet Highway which is commonly known $\mathrm{NH}-05$ (previously known as $\mathrm{NH}-22$ ) (Figure 10). These activities have enough capacity to change the pattern of land use (Pandey 2011). Due to changes in land use pattern habitat of many wild animals is shifted from the lower area to the upper cold region, which leads to mal-adaptation for them. Activities, like road construction, tunnelling for the HEP dam construction in the river, government officials building, necessary amenities shops near the highways, mining activities in the highland area lead to a high risk of environmental degradation (Figure 11).

Table 4. Land Use/Land Cover Change Detection Matrix, 2005-2018

\begin{tabular}{|c|c|c|c|c|c|c|c|c|}
\hline \multicolumn{9}{|c|}{2018} \\
\hline & $\begin{array}{l}\text { LULC } \\
\text { CLASS }\end{array}$ & Built-up & Snow & Vegetation & Water & Wasteland & Agriculture & Total \\
\hline 2 & Built-up & 8 & 0 & 0 & 0 & 0 & 0 & 8 \\
\hline 0 & Snow & 0 & 439 & 0 & 0 & 0 & 0 & 439 \\
\hline 0 & Vegetation & 0 & 0 & 331 & 0 & 3 & 5 & 339 \\
\hline 5 & Water & 0 & 0 & 0 & 1 & 0 & 0 & 1 \\
\hline & Wasteland & 9 & 186 & 36 & 8 & 1092 & 296 & 1626 \\
\hline & Agriculture & 0 & 0 & 0 & 0 & 0 & 90 & 90 \\
\hline & Total & 17 & 625 & 368 & 9 & 1095 & 390 & \\
\hline
\end{tabular}

Source: Calculated by the author with the help of the LANDSAT imageries.

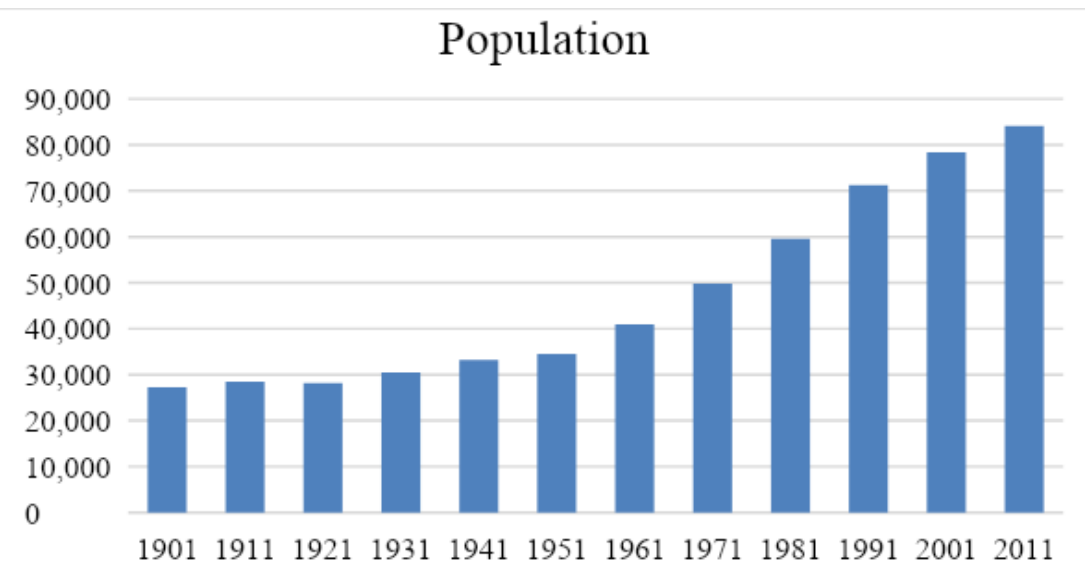

Figure 9. Population of Kinnaur District from 1901 to 2011. Source: Census of India, 2011 


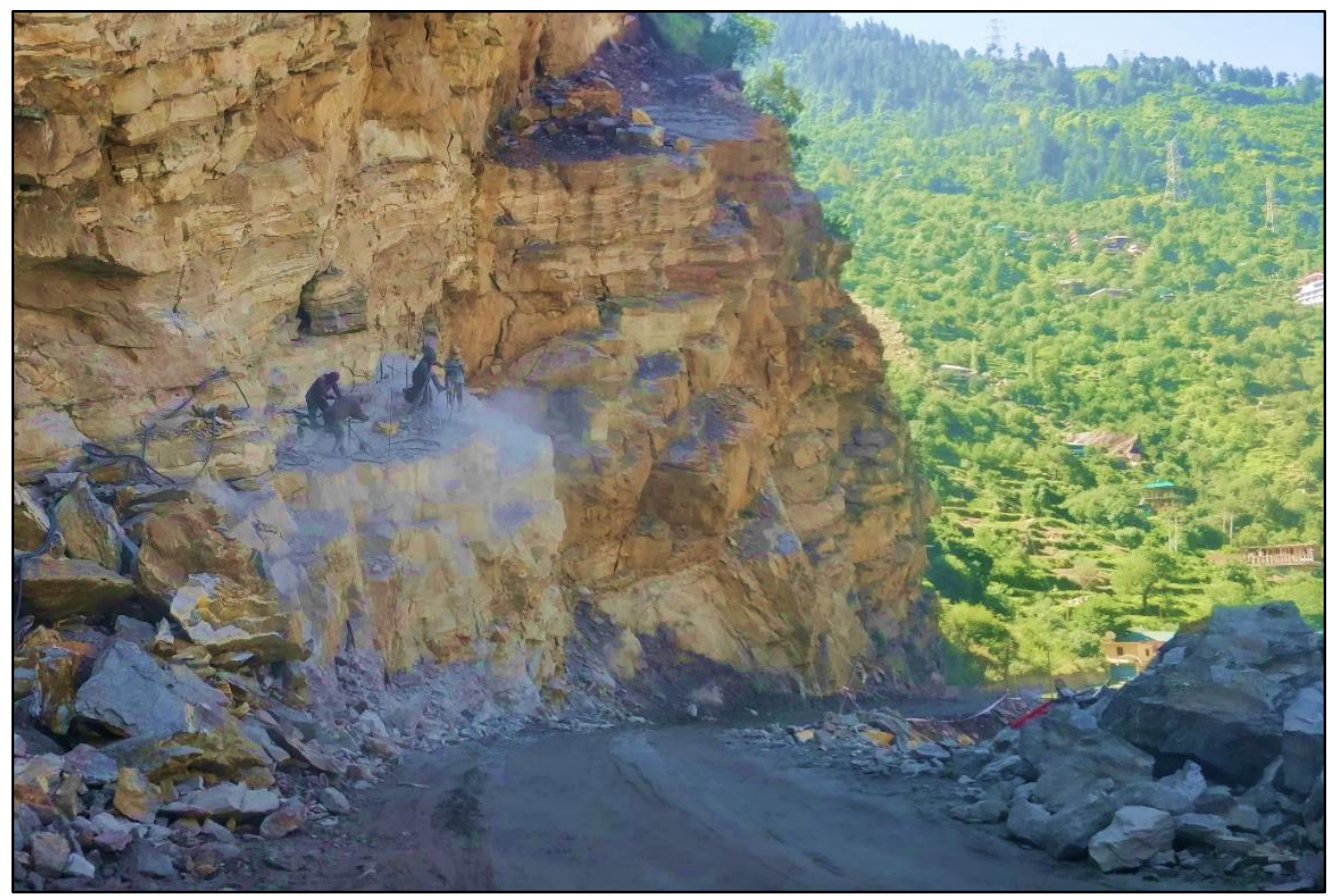

Figure 10. Road widening (Men at work) on NH-5 connect Shimla to Kaza via Kinnaur. Source: Primary Survey, 2017.

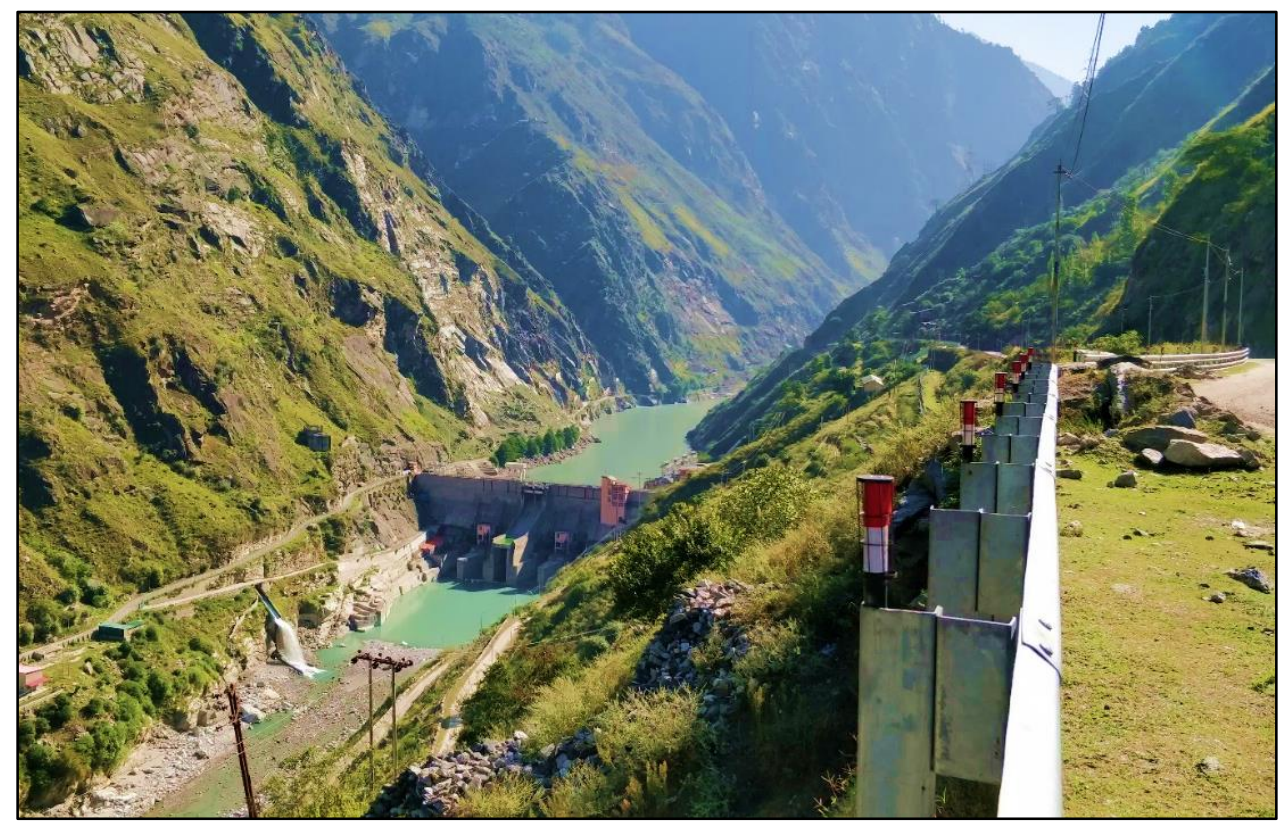

Figure 11. Shows the Nathpa Dam (Part of Nathpa Jhakari HEP) on Sutlej river in Nichar Valley of Kinnaur Distrcit..Source: Primary Survey, 2017.

As conclusion, Himalayas are one of the youngest fold mountains and at the same time it is highly densely inhabited in comparison to other mountain system, which makes it more prone to exploitation through extreme anthropogenic activities, mainly because of rapid changes in land-use patterns. Kinnaur, situated in Western Himalaya, has constrained livelihood opportunities and the existing indigenous livelihood practices and knowledge are adversely affected by continuous changes in the nature of land use/land 
cover. The described figures and tables represent the present condition of the district and show an analogous study of the land-use pattern of the district for the few decades, i.e. 1990, 2005, and 2018. Findings clearly shows more pronounced increase in built-up land, agriculture land, and vegetation including horticultural land. Recent development activities in the district, merely started from 1990 s to 2010 , and this study give a brief glance about the changing pattern of land use. Nevertheless, decreasing area of wasteland shows that it is transformed into other land use pattern due to the pressure of increased population and high reliance on natural resources. These changes cannot be neglected and are evidence for the exploitation of groundwater explicitly in the form of springs as well. Uncertain tunnelling has dried up the upper streams and moreover, the excessive point of flow in the lower areas has negatively contributed in the changes of land use pattern in the form of mass wasting and landslides. Adequate level of development activities is essential for the well-being of human civilization and nation, but extreme and unbalanced way of development has damaging impact on the essence of well-being of nation and its citizen. Therefore, it is indispensable to have a sustainable development mechanism for the fragile and endangered ecosystem. However, it can be only achieved by the collaboration and the initiatives taken by the local government and Corporate Social Responsibility (CSR). Additionally, the government agencies and global partners must be involved into the improvement of the degraded land condition for further sustainability of the region which directly contributes to provide good agriculture output and leads to availability of quality foods and more livelihood option for the people of the region.

\section{REFERENCES}

Chawla, A., Kumar, A., Lal, B., Singh, R. D., \& Thukral, A. K. 2012. Ecological Characterization of High Altitude Himalayan Landscapes in the Upper Sutlej River Watershed, Kinnaur, Himachal Pradesh, India. Journal of the Indian Society of Remote Sensing, 40(3), 519-539.

Gupta, H. K. 2007. Deforestation and forest cover changes in the Himachal Himalaya, India. International Journal of Ecology and Environmental Sciences, 33(2-3), 207218.

Kumar, A., Uniyal, S. K., \& Singh, R. D. 2013. Land Use and Land Cover Patterns of Indian Western Himalaya. Climate Change and its Ecological Implications for the Western Himalaya, 49.

Lambin, E.F., Turner, B.L., Geist, H.J., Agbola, S.B., Angelsen, A., Bruce, J.W., Coomes, O.T., Dirzo, R., Fischer, G., Folke, C. and George, P. 2001. The causes of landuse and land-cover change: moving beyond the myths. Global environmental change, 11(4), 261-269.

Lata, R., Rishi, S., Talwar, D., \& Dolma, K. 2015. Comparative Study of Land Use Pattern in the Hilly Area of Kinnaur district, Himachal Pradesh, India. International Journal of Innovative Science, Engineering and Technology, 2(4), 559-565.

Mahmood, R., Pielke Sr, R.A., Hubbard, K.G., Niyogi, D., Bonan, G., Lawrence, P., McNider, R., McAlpine, C., Etter, A., Gameda, S. and Qian, B. 2010. Impacts of land use/land cover change on climate and future research priorities. Bulletin of the American Meteorological Society, 91(1), 37-46.

Maurya, R. \& Mishra, H. 2017. Impact Assessment of Cultivated Land and forest Products on Livelihood Security of Tribal Community in Kinnaur District, Himachal Pradesh. In V.S. Negi, B.W. Pandey, \& Kumaria P. (Eds.), Whither Sustainable 
Development: Studies in Planning and Management of Land and Water Resources (pp. 279-294). Research India Press.

Negi, S. P. 2009. Forest cover in Indian Himalayan states-An overview. Indian Journal of Forestry, 32(1), 1-5.

Pandey, R., \& Jha, S. 2012. Climate vulnerability index-measure of climate change vulnerability to communities: a case of rural Lower Himalaya, India. Mitigation and Adaptation Strategies for Global Change, 17(5), 487-506.

Pandey, R., Jha, S. K., Alatalo, J. M., Archie, K. M., \& Gupta, A. K. 2017. Sustainable livelihood framework-based indicators for assessing climate change vulnerability and adaptation for Himalayan communities. Ecological indicators, 79, 338-346.

Pandey, B. W. 2011. In search of sustainability: global perspective on marginality, technology, politics and planning of land use. Research India Press.

Pandey, B. W. (2002). Geoenvironmental Hazards in Himalaya: Assessment and Mapping. Mittal Publication, New Delhi.

Prasad, A. S., Pandey, B. W., Leimgruber, W., \& Kunwar, R. M. 2016. Mountain hazard susceptibility and livelihood security in the upper catchment area of the river Beas, Kullu Valley, Himachal Pradesh, India. Geoenvironmental Disasters, 3(1), 3.

Reid, R. S., Kruska, R. L., Muthui, N., Taye, A., Wotton, S., Wilson, C. J., \& Mulatu, W. 2000. Land-use and land-cover dynamics in response to changes in climatic, biological and socio-political forces: the case of southwestern Ethiopia. Landscape Ecology, 15(4), 339-355.

Singh, K., Sharma, P. D., \& Bhandari, A. R. 1992. Land capability classes and management needs for sustained productivity in semi-arid regions of north-west Himalayas (Vol. 2, pp. 51-57). Agropedology.

Singh, R. B. 1996. Remote Sensing and GIS Based Land Use Information System for Natural Resource Monitoring and Management: The Indian Experience in Proceedings of Int. In Workshop held at Ullan Bataar, Nagoya, UNCRD (pp. 99106).

Singh, R. B., \& Pandey, B. W. 1995. Common resources and sustainable livelihoods of mountain environments: A micro-level experience of Upper Kulu Valley. Sustainable Reconstruction of Highland and Headwater Regions. Oxford and IBH Publishing, New Delhi, 663-681.

Received: 31th March 2020; Accepted: 31th April 2020; Published: 01th Jule 2020. 